\title{
Nocardiopsis valliformis sp. nov., an alkaliphilic actinomycete isolated from alkali lake soil in China
}

\author{
Correspondence \\ Li-Ping Zhang \\ zhlping@mail.hbu.edu.cn
}

\author{
Runlei Yang, Li-Ping Zhang, Li-Ge Guo, Nan Shi, Zhitang Lu \\ and Xiumin Zhang
}

College of Life Sciences, HeBei University, The Key Laboratory of Microbial Diversity Research and Application of Hebei Province, Baoding 071002, PR China
The genus Nocardiopsis was first described by Meyer (1976) based on morphological characteristics and the chemical composition of cells. The genus Nocardiopsis currently contains 24 species and two subspecies: Nocardiopsis dassonvillei subsp. dassonvillei (Meyer, 1976), N. alba, N. listeri (Grund \& Kroppenstedt, 1990), N. halophila (Al-Tai \& Ruan, 1994), N. lucentensis (Yassin et al., 1993), N. prasina, N. synnemataformans (Yassin et al., 1997), N. kunsanensis (Chun et al., 2000), N. tropica, N. trehalosi, N. dassonvillei subsp. albirubida (Evtushenko et al., 2000), N. exhalans, N. umidischolae (Peltola et al., 2001), N. halotolerans (Al-Zarban et al., 2002), N. composta (Kämpfer et al., 2002), N. metallicus (Schippers et al., 2002), N. xinjiangensis ( $\mathrm{Li}$ et al., 2003), N. alkaliphila (Hozzein et al., 2004), N. salina (Li et al., 2004), N. aegyptica (Sabry et al., 2004), N. baichengensis, $N$. chromatogenes, N. gilva, N. rhodophaea and $N$. rosea (Li et al., 2006). Most species are alkaliphilic or halophilic. Because of the discovery of novel taxa and many new valuable secondary metabolites, more and more scientists are now searching extreme environments and studying their unusual actinomycetes.

In this paper, we isolated some strains of alkaline actinomycetes from Xinjiang, a region of western China.

The GenBank/EMBL/DDBJ accession number for the 16S rRNA gene sequence of strain HBUM $20028^{\top}$ is AY336503.
Strain HBUM $20028^{\mathrm{T}}$ was identified by a polyphasic approach. Comparative studies of morphology, physiology, biochemistry and chemical composition of cells, phylogenetic analysis based on $16 \mathrm{~S}$ rRNA gene sequences and DNA relatedness tests were carried out between strain HBUM $20028^{\mathrm{T}}$ and type strains of the genus Nocardiopsis. The results indicated that the novel strain belongs to the genus Nocardiopsis and is different from known members of the genus. Therefore, we consider that strain HBUM $20028^{\mathrm{T}}$ represents a novel species of the genus Nocardiopsis.

Strain HBUM $20028^{\mathrm{T}}$ used in this study was isolated from a soil sample collected from an alkali lake near the county of Buerjin (Xinjiang, China) by using agar plates containing DSMZ medium no. 852 (GYP medium, adjusted to pH 10.0 with sterile saturated sodium carbonate solution after sterilization). Strain HBUM $20028^{\mathrm{T}}$ was cultured for 3, 5, 7 and 14 days at $28{ }^{\circ} \mathrm{C}$ and pH 10.0 on GYP agar and then observed by using a model BH-2 Olympus light microscope and a model KYKY-AMRAY-100B scanning electron microscope.

Cultural characteristics were studied by using 7-day-old cultures grown at $28{ }^{\circ} \mathrm{C}$ and $\mathrm{pH} 10.0$ on GYP agar media. Vegetative and aerial mycelium of strain HBUM $20028^{\mathrm{T}}$ grew well on GYP medium and the aerial mycelium was usually abundant and white to yellowish, dividing into rodshaped, smooth-surfaced and non-motile spores (0.3$0.5 \times 1.2-2.5 \mu \mathrm{m})$, but the substrate mycelium was yellow 
to light-brown and was often arranged in a shape like a palisade (Fig. 1).

The physiological characteristics of the strain were tested according to Holt et al. (1994). The optimal growth temperature was $28{ }^{\circ} \mathrm{C}$. The optimal $\mathrm{pH}$ for growth was $\mathrm{pH} 9.5-13$, and the strain had a broad $\mathrm{pH}$ range for growth, from $\mathrm{pH} 8.0$ to 14.0 , but did not grow at $\mathrm{pH} 7.0$, demonstrating that strain HBUM $20028^{\mathrm{T}}$ is strongly alkaliphilic. Other physiological and biochemical properties are presented in Table 1.

Biomass used for chemotaxonomic and molecular systematic studies was cultivated in GYP liquid medium on a shaking incubator for 4 days at $28{ }^{\circ} \mathrm{C}$; cells were then harvested by centrifugation and washed with distilled water. Amino acids of purified cell walls were analysed by using the method of Lechevalier \& Lechevalier (1980). Diagnostic sugars of whole-cell hydrolysates were determined by using the methods of Hasegawa et al. (1983). Menaquinones were determined as described by Collins (1985). Phospholipids were prepared and identified by referring to the methods of Lechevalier \& Lechevalier (1980). The cellular fatty acid composition was studied as described by Sasser (1990), using the Microbial Identification System (MIDI). Cell walls of strain HBUM $20028^{\mathrm{T}}$ contained meso-diaminopimelic acid, but did not contain any diagnostic sugars. It can be considered to have a type III/C cell wall. Phospholipids consisted of diphosphatidylglycerol and phosphatidylcholine, which belong to the type PIII phospholipid pattern based on Lechevalier \& Lechevalier (1980). The major menaquinones of the strain were MK-10 $\left(\mathrm{H}_{2}\right)$, MK-10 $\left(\mathrm{H}_{4}\right)$ and MK-10 $\left(\mathrm{H}_{6}\right)$ and the major cellular fatty acids were iso- $\mathrm{C}_{16: 0}(31.66 \%)$, anteiso- $\mathrm{C}_{17: 0}(14.85 \%)$ and $\mathrm{C}_{18: 1} \omega 9 c(14.73 \%)$.

Chromosomal DNA of strain HBUM $20028^{\mathrm{T}}$ was prepared by referring to the methods of Marmur (1961) and Kutchma et al. (1998). The DNA G+C content was determined according to the methods of Mesbah et al.
(1989). The DNA was treated with BAL31 nuclease and alkaline phosphatase and mononucleotides were determined by HPLC. The $16 \mathrm{~S}$ rRNA gene was amplified by PCR (TGRADIENT; Biometra) using Taq DNA polymerase (Sangon). Universal primers for actinomycetes were used, primers 27f (5'-GAGTTTGATCCTGGCTCAG-3'; Eschierchia coli positions 8-27) and 1525r (5'AGAAAGGAGGTGTACCAGCC-3'; E. coli positions 1525-1545) (Lane et al., 1985), and the $1.5 \mathrm{~kb}$ amplified $16 \mathrm{~S}$ rRNA gene fragment was purified and sequenced by Sangon Biological Engineering Co. Ltd (Shanghai). The same primers (27f and 1525r) were used for terminal sequencing. The internal sequencing primer used was $\mathrm{P} 3$ (5'-CTAACTACGTGCCAGCAGCC- $3^{\prime}$ ). The $16 \mathrm{~S}$ rRNA gene sequences of type strains of related species were obtained from GenBank. 16S rRNA gene sequences were aligned manually with sequences of members of the genus Nocardiopsis by using CLUSTAL_X 1.81 (Thompson et al., 1997). The evolutionary tree was inferred by using the neighbour-joining method (Saitou \& Nei, 1987). The topology of the resultant tree was evaluated by bootstrap analysis (Felsenstein, 1985) of the neighbour-joining data based on 1000 replications. All phylogenetic analyses were inferred by using the PHYLIP software package (Felsenstein, 2001). The phylogenetic tree was rebuilt by TreeView (Page, 1996).

The nearly complete 16S rRNA gene sequence of strain HBUM $20028^{\mathrm{T}}$ was determined and consisted of $1434 \mathrm{bp}$. Preliminary comparison of the sequence against those in GenBank indicated that members of the genus Nocardiopsis were the closest phylogenetic neighbours. Binary similarity values of this strain and type strains of other species of the genus Nocardiopsis ranged between $93.98 \%$ (N. rhodophaea YIM $\left.90096^{\mathrm{T}}\right)$ and $99.93 \%\left(N\right.$. exhalans ES10.1 $\left.{ }^{\mathrm{T}}\right)$. The results show that strains HBUM $20028^{\mathrm{T}}, N$. exhalans ES10. $1^{\mathrm{T}}$, N. metallicus $\mathrm{KBS6}^{\mathrm{T}}$ and N. prasina DSM $43845^{\mathrm{T}}$ were clustered into a branch. Fig. 2 shows the neighbourjoining tree. Sequence similarity calculations after a
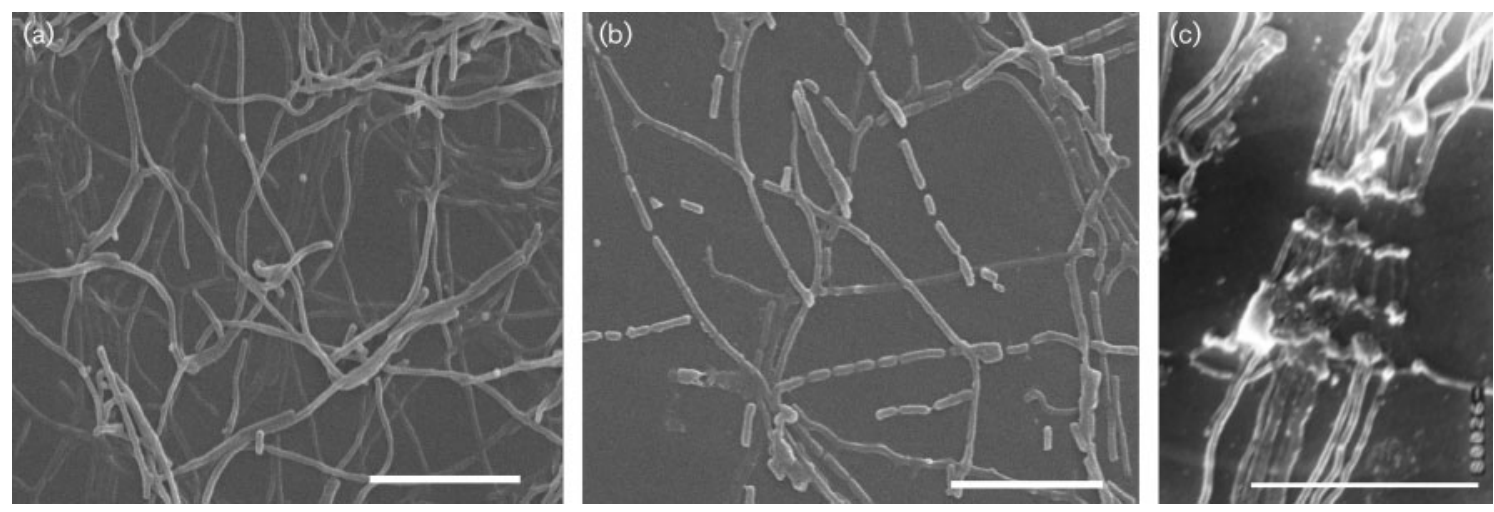

Fig. 1. Scanning electron micrographs of strain HBUM $20028^{\top}$ showing the long-branched hyphae $(\times 3000)($ a), aerial mycelium dividing into rod-shaped spores (b) and mycelium arranged in a palisade-like shape and divided (c). Original magnification, $\times 3000(\mathrm{a}, \mathrm{b})$ and $\times 5000(\mathrm{c})$. Bars, $10 \mu \mathrm{m}$. 
Table 1. Differential phenotypic characteristics of HBUM $20028^{\top}$ and the type strains of closely related Nocardiopsis species

Strains: 1, N. valliformis sp. nov. HBUM $20028^{\mathrm{T}} ; 2$, N. prasina DSM 43845 ${ }^{\mathrm{T}} ; 3$, N. metallicus DSM 44598 ${ }^{\mathrm{T}} ; 4$, N. exhalans DSM 44407 ${ }^{\mathrm{T}}$. +, Positive; -, negative; V, not confirmed; ND, no data available. Data for reference strains were taken from Yassin et al. (1997), Peltola et al. (2001) and Schippers et al. (2002). All strains are positive for growth at $28{ }^{\circ} \mathrm{C}$, nitrate reduction and utilization of L-arabinose, D-xylose and glycerol and negative for growth at $45{ }^{\circ} \mathrm{C}, \mathrm{H}_{2} \mathrm{~S}$ production, formation of melanin on tyrosine agar (ISP 6) and peptone-yeast-iron agar (ISP 7) and utilization of myo-inositol.

\begin{tabular}{|c|c|c|c|c|}
\hline Characteristic & 1 & 2 & 3 & 4 \\
\hline Aerial mycelium & White to yellowish & White & White & White \\
\hline Colony pigmentation (ISP 5) & White & White & Pale yellow & Light yellow \\
\hline Optimal $\mathrm{pH}$ for growth & $9.5-13$ & 10.0 & 8.5 & 7.2 \\
\hline \multicolumn{5}{|l|}{ Utilization of: } \\
\hline Sucrose & - & - & + & + \\
\hline L-Rhamnose & $\mathrm{v}$ & - & + & + \\
\hline Lactose & + & - & - & - \\
\hline Cellobiose & $\mathrm{v}$ & - & + & + \\
\hline \multicolumn{5}{|l|}{ Growth at: } \\
\hline $10{ }^{\circ} \mathrm{C}$ & - & - & + & + \\
\hline $42{ }^{\circ} \mathrm{C}$ & - & + & - & - \\
\hline Growth in $10 \% \mathrm{NaCl}$ & - & + & + & + \\
\hline Gelatin liquefaction & + & + & - & + \\
\hline Major menaquinones & $10\left(\mathrm{H}_{2}\right), 10\left(\mathrm{H}_{4}\right), 10\left(\mathrm{H}_{6}\right)$ & $10\left(\mathrm{H}_{4}\right), 10\left(\mathrm{H}_{6}\right)$ & ND & $10\left(\mathrm{H}_{6}\right), 10\left(\mathrm{H}_{8}\right)$ \\
\hline Major phospholipids* & DPG, PC & PC, PME & $\mathrm{ND}$ & PC, PI, PG, PME, DPG \\
\hline $\begin{array}{l}\text { Major cellular fatty acids } \dagger \\
(>10 \%)\end{array}$ & $\begin{array}{l}\mathrm{i}-\mathrm{C}_{16: 0}(32 \%), \text { ai- } \mathrm{C}_{17: 0} \\
(15 \%), \mathrm{C}_{18: 1} \omega 9 c(15 \%)\end{array}$ & $\begin{array}{c}\text { 10-Me } \mathrm{C}_{18: 0}(21 \%), \mathrm{i}-\mathrm{C}_{16: 0} \\
(21 \%), \text { ai- } \mathrm{C}_{17: 0}(18 \%)\end{array}$ & $\begin{array}{c}\mathrm{i}-\mathrm{C}_{16: 0}(26 \%), \mathrm{C}_{18: 1} \omega 9 c \\
(23 \%), \text { ai- } \mathrm{C}_{17: 0}(15 \%)\end{array}$ & $\begin{array}{c}\mathrm{i}-\mathrm{C}_{16: 0}(22 \%), 10-\mathrm{Me} \\
\mathrm{C}_{18: 0}(12 \%), \text { ai- } \mathrm{C}_{17: 0} \\
(11 \%)\end{array}$ \\
\hline DNA G $+C$ content $(\mathrm{mol} \%)$ & 70.6 & 68.1 & 70.8 & 71.0 \\
\hline
\end{tabular}

*DPG, Diphosphatidylglycerol; PC, phosphatidylcholine; PG, phosphatidylglycerol; PI, phosphatidylinositol; PME, phosphatidylmonomethanolamine.

†ai, Anteiso-branched; i, iso-branched; Me, methyl.

neighbour-joining analysis indicated that the closest relatives of strain HBUM $20028^{\mathrm{T}}$ were $N$. exhalans ES10.1 $1^{\mathrm{T}}$ (99.93\% 16S rRNA gene sequence similarity), $N$. metallicus $\mathrm{KBS6}^{\mathrm{T}}(99.58 \%)$ and N. prasina DSM $43845^{\mathrm{T}}$ (99.22\%). The G + C content of the DNA of strain HBUM $20028^{\mathrm{T}}$ was $70.6 \mathrm{~mol} \%$.

DNA-DNA hybridization studies were performed by the initial reassociation-rate method (De Ley et al., 1970) using a spectrophotometer (model CE9500; CECIL Company) equipped with a programmable melting temperature control unit. DNA of strain HBUM $20028^{\mathrm{T}}$ was hybridized with that of $N$. exhalans DSM $44407^{\mathrm{T}}$, N. metallicus DSM $44598^{\mathrm{T}}$ and $N$. prasina DSM $43845^{\mathrm{T}}$, the closest phylogenetic neighbours. The levels of DNA-DNA relatedness with the three strains were $31.4,20.3$ and $24.6 \%$, respectively.

Phenotypic and genotypic characteristics provided clear evidence that strain HBUM $20028^{\mathrm{T}}$ belongs to the genus Nocardiopsis. The phylogenetic position of this strain is within a cluster that contains $N$. exhalans, N. metallicus and $N$. prasina. However, strain HBUM $20028^{\mathrm{T}}$ can be differentiated from other species by its morphological, physiological and chemotaxonomic characteristics (Table 1). The values of DNA-DNA relatedness of strain HBUM
$20028^{\mathrm{T}}$ with related type strains were found to be $<70 \%$. Based on the above results, it is concluded that strain HBUM $20028^{\mathrm{T}}$ represents a novel species of the genus Nocardiopsis, for which the name Nocardiopsis valliformis sp. nov. is proposed.

\section{Description of Nocardiopsis valliformis sp. nov.}

Nocardiopsis valliformis (val.li.for'mis. L. n. vallum palisade; L. adj. suffix -formis -like, in the shape of; N.L. fem. adj. valliformis shaped like a palisade, referring to the characteristic mycelium, which is often arranged in a shape like a palisade).

Aerial mycelium is abundant and white to yellowish, and fragments into rod-shaped, smooth-surfaced and nonmotile spores $(0.3-0.5 \times 1.2-2.5 \mu \mathrm{m})$. Substrate mycelium is yellow to light-brown and is often arranged in a shape like a fence or palisade. Aerobic, Gram-positive. Optimal growth temperature is $28{ }^{\circ} \mathrm{C}$; no growth at 10,42 and $45^{\circ} \mathrm{C}$. Optimal $\mathrm{pH}$ for growth is $\mathrm{pH}$ 9.5-13; has a broad range of growth $\mathrm{pH}$, from $\mathrm{pH} 8.0$ to 14.0 . No growth at $\mathrm{pH}$ 7.0. Growth occurs in the absence of $\mathrm{NaCl}$ and in 1,3 and $5 \% \mathrm{NaCl}$; no growth in $10 \% \mathrm{NaCl}$. L-Arabinose, Dxylose, lactose and glycerol are utilized, but not sucrose or 


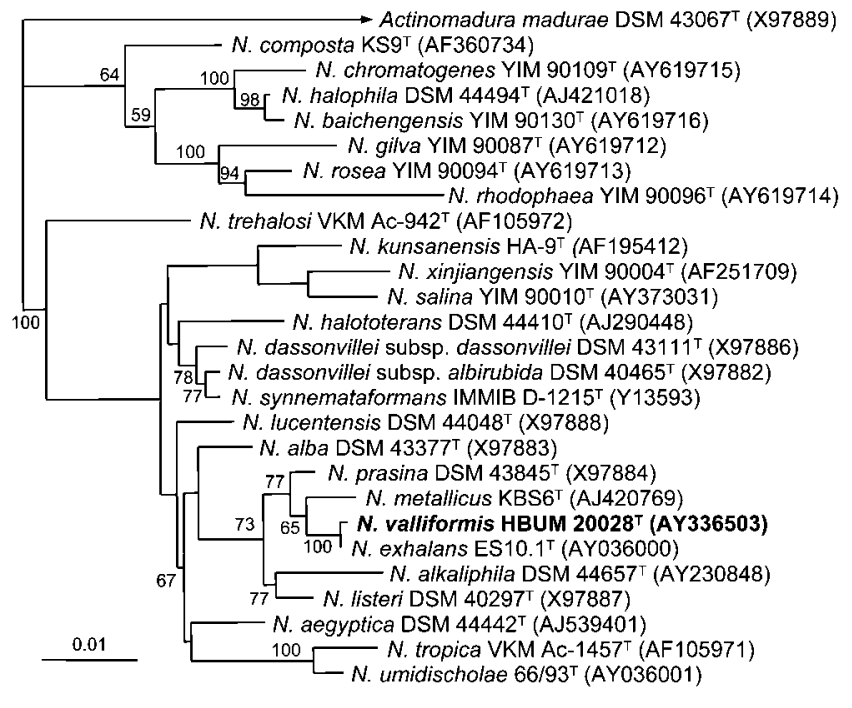

Fig. 2. Phylogenetic tree based on $16 \mathrm{~S}$ rRNA gene sequence analysis, showing the phylogenetic position of strain HBUM $20028^{\top}$ (Nocardiopsis valliformis sp. nov.) compared with the other species of the genus Nocardiopsis. The sequence of Actinomadura madurae DSM $43067^{\top}$ served as an outgroup. Bootstrap values $>50 \%$ are shown at nodes of the tree. Bar, 0.01 substitutions per nucleotide position.

myo-inositol. Nitrate reduction and gelatin liquefaction are positive; $\mathrm{H}_{2} \mathrm{~S}$ production is negative. Melanin is not observed on either tyrosine agar or peptone-yeast-iron agar (ISP media 6 and 7). Whole-cell hydrolysates of the type strain contain meso-diaminopimelic acid but no diagnostic sugar. Major phospholipids include diphosphatidylglycerol and phosphatidylcholine, which belong to the type PIII phospholipids pattern based on Lechevalier \& Lechevalier (1980). Major menaquinones are MK$10\left(\mathrm{H}_{2}\right), \mathrm{MK}-10\left(\mathrm{H}_{4}\right)$ and $\mathrm{MK}-10\left(\mathrm{H}_{6}\right)$. Major cellular fatty acids are iso- $\mathrm{C}_{16: 0}(31.66 \%)$, anteiso- $\mathrm{C}_{17: 0}(14.85 \%)$ and $\mathrm{C}_{18: 1} \omega 9 c(14.73 \%)$. The $\mathrm{G}+\mathrm{C}$ of the DNA of the type strain is $70.6 \mathrm{~mol} \%$ (HPLC).

The type strain, HBUM $20028^{\mathrm{T}}\left(=\mathrm{DSM} 45023^{\mathrm{T}}=\mathrm{CGMCC}\right.$ $4.2135^{\mathrm{T}}$ ), was isolated from a soil sample collected from an alkali lake in Xinjiang, China.

\section{Acknowledgements}

This work was supported by the National Natural Science Foundation of China (3027002).

\section{References}

Al-Tai, A. M. \& Ruan, J.-S. (1994). Nocardiopsis halophila sp. nov., a new halophilic actinomycete isolated from soil. Int J Syst Bacteriol 44, 474-478.

Al-Zarban, S. S., Abbas, I., Al-Musallam, A. A., Steiner, U., Stackebrandt, E. \& Kroppenstedt, R. M. (2002). Nocardiopsis halotolerans sp. nov., isolated from salt marsh soil in Kuwait. Int $J$ Syst Evol Microbiol 52, 525-529.

Chun, J., Bae, K. S., Moon, E. Y., Jung, S.-O., Lee, H. K. \& Kim, S.-J. (2000). Nocardiopsis kunsanensis sp. nov., a moderately halophilic actinomycete isolated from a saltern. Int J Syst Evol Microbiol 50, 1909-1913.

Collins, M. D. (1985). Analysis of isoprenoid quinones. Methods Microbiol 18, 329-366.

De Ley, J., Cattoir, H. \& Reynaerts, A. (1970). The quantitative measurement of DNA hybridization from renaturation rates. Eur $J$ Biochem 12, 133-142.

Evtushenko, L. I., Taran, V. V., Akimov, V. N., Kroppenstedt, R. M., Tiedje, J. M. \& Stackebrandt, E. (2000). Nocardiopsis tropica sp. nov., Nocardiopsis trehalosi sp. nov., nom. rev. and Nocardiopsis dassonvillei subsp. albirubida subsp. nov., comb. nov. Int J Syst Evol Microbiol 50, 73-81.

Felsenstein, J. (1985). Confidence limits on phylogenies: an approach using the bootstrap. Evolution 39, 783-791.

Felsenstein, J. (2001). PHYLIP (phylogeny inference package), version 3.6 (alpha2). Distributed by the author. Department of Genome Sciences, University of Washington, Seattle, USA.

Grund, E. \& Kroppenstedt, R. M. (1990). Chemotaxonomy and numerical taxonomy of the genus Nocardiopsis Meyer 1976. Int J Syst Bacteriol 40, 5-11.

Hasegawa, T., Takizawa, M. \& Tanida, S. (1983). A rapid analysis for chemical grouping of aerobic actinomycetes. J Gen Appl Microbiol 29, 319-322.

Holt, J. G., Krieg, N. R. \& Sneath, P. H. A. (editors) (1994). Bergey's Manual of Determinative Bacteriology, 9th edn. Baltimore: Williams \& Wilkins.

Hozzein, W. N., Li, W.-J., Ali, M. L. A., Hammouda, O., Mousa, A. S., Xu, L.-H. \& Jiang, C.-L. (2004). Nocardiopsis alkaliphila sp. nov., a novel alkaliphilic actinomycete isolated from desert soil in Egypt. Int $J$ Syst Evol Microbiol 54, 247-252.

Kämpfer, P., Busse, H.-J. \& Rainey, F. A. (2002). Nocardiopsis compostus sp. nov., from the atmosphere of a composting facility. Int $J$ Syst Evol Microbiol 52, 621-627.

Kutchma, A. J., Roberts, M. A., Knaebel, D. B. \& Crawford, D. L. (1998). Small-scale isolation of genomic DNA from Streptomyces mycelia or spores. Biotechniques 24, 452-457.

Lane, D. J., Pace, B., Olsen, G. J., Stahl, D. A., Sogin, M. L. \& Pace, N. R. (1985). Rapid determination of $16 \mathrm{~S}$ ribosomal RNA sequences for phylogenetic analyses. Proc Natl Acad Sci U S A 82, 6955-6959.

Lechevalier, H. A. \& Lechevalier, M. P. (1980). The chemotaxonomy of actinomycetes. In Actinomycete Taxonomy, pp. 227-291. Special Publication no. 6. Edited by A. Dietz \& D. W. Thayer. Arlington, VA: Society for Industrial Microbiology.

Li, M.-G., Li, W.-J., Xu, P., Cui, X.-L. \& Xu, L.-H. (2003). Nocardiopsis xinjiangensis sp. nov., a halophilic actinomycete isolated from a saline soil sample in China. Int J Syst Evol Microbiol 53, 317-321.

Li, W.-J., Park, D.-J., Tang, S.-K., Wang, D., Lee, J.-C., Xu, L.-H., Kim, C.-J. \& Jiang, C.-L. (2004). Nocardiopsis salina sp. nov., a novel halophilic actinomycete isolated from saline soil in China. Int J Syst Evol Microbiol 54, 1805-1809.

Li, W.-J., Kroppenstedt, R. M., Wang, D., Tang, S.-K., Lee, J.-C., Park, D.-J., Kim, C.-J., Xu, L.-H. \& Jiang, C.-L. (2006). Five novel species of the genus Nocardiopsis isolated from hypersaline soils and emended description of Nocardiopsis salina Li et al. 2004. Int J Syst Evol Microbiol 56, 1089-1096.

Marmur, J. (1961). A procedure for the isolation of deoxyribonucleic acid from microorganisms. J Mol Biol 3, 208-218. 
Mesbah, M., Premachandran, U. \& Whitman, W. B. (1989). Precise measurement of the $\mathrm{G}+\mathrm{C}$ content of deoxyribonucleic acid by highperformance liquid chromatography. Int J Syst Bacteriol 39, 159-167.

Meyer, J. (1976). Nocardiopsis, a new genus of the order Actinomycetales. Int J Syst Bacteriol 26, 487-493.

Page, R. D. M. (1996). TreeView: an application to display phylogenetic trees on personal computers. Comput Appl Biosci 12, 357-358.

Peltola, J. S. P., Andersson, M. A., Kämpfer, P., Auling, G., Kroppenstedt, R. M., Busse, H.-J., Salkinoja-Salonen, M. S. \& Rainey, F. A. (2001). Isolation of toxigenic Nocardiopsis strains from indoor environments and description of two new Nocardiopsis species, $N$. exhalans sp. nov. and N. umidischolae sp. nov. Appl Environ Microbiol 67, 4293-4304.

Sabry, S. A., Ghanem, N. B., Abu-Ella, G. A., Schumann, P., Stackebrandt, E. \& Kroppenstedt, R. M. (2004). Nocardiopsis aegyptia sp. nov., isolated from marine sediment. Int J Syst Evol Microbiol 54, $453-456$.

Saitou, N. \& Nei, M. (1987). The neighbor-joining method: a new method for reconstructing phylogenetic trees. Mol Biol Evol 4, 406-425.
Sasser, M. (1990). Identification of bacteria by gas chromatography of cellular fatty acids, MIDI Technical Note 101. Newark, DE: MIDI Inc.

Schippers, A., Bosecker, K., Willscher, S., Spröer, C., Schumann, P. \& Kroppenstedt, R. M. (2002). Nocardiopsis metallicus sp. nov., a metal-leaching actinomycete isolated from an alkaline slag dump. Int J Syst Evol Microbiol 52, 2291-2295.

Thompson, J. D., Gibson, T. J., Plewniak, F., Jeanmougin, F. \& Higgins, D. G. (1997). The CLUSTAL_X windows interface: flexible strategies for multiple sequence alignment aided by quality analysis tools. Nucleic Acids Res 25, 4876-4882.

Yassin, A. F., Galinski, E. A., Wohlfarth, A., Jahnke, K.-D., Schaal, K. P. \& Trüper, H. G. (1993). A new actinomycete species, Nocardiopsis lucentensis sp. nov. Int J Syst Bacteriol 43, 266-271.

Yassin, A. F., Rainey, F. A., Burghardt, J., Gierth, D., Ungerechts, J., Lux, I., Seifert, P., Bal, C. \& Schaal, K. P. (1997). Description of Nocardiopsis synnemataformans sp. nov., elevation of Nocardiopsis alba subsp. prasina to Nocardiopsis prasina comb. nov., and designation of Nocardiopsis antarctica and Nocardiopsis alborubida as later subjective synonyms of Nocardiopsis dassonvillei. Int J Syst Bacteriol 47, 983-988. 